\title{
Heterosis and combining ability estimates for the total number of eggs laid per female in silkworm, Bombyx mori L.
}

\author{
${ }^{2} \mathrm{H}$ A Rashid, ${ }^{1} \mathrm{~S} M \mathrm{Mahman}$, and ${ }^{1} \mathrm{M} \mathrm{K}$ Ahsan
}

${ }^{1}$ Department of Zoology, Rajshahi University. ${ }^{2}$ Govt. Rajendra College, Faridpur

\begin{abstract}
Heterosis and combining ability for total number of eggs laid per female silkworm Bombyx mori $\mathrm{L}$ were investigated in a six parent diallel crossing programme in four rearing seasons. Magnitude of heterosis varied from seasons to season and was not consistent over characters. Effect of season was important in the expression of genetic variances and other parameters studied. Considerable amount to heterosis was obtained in the crosses where parents Nistari Oval (G), BSRI-98 and BV-High were involved. Parental performance as judged by general combining ability quantities indicated that BSRI-98 was the best general combining parent in all the rearing seasons. The variance due to the specific combing ability $\left(\sigma^{2}\right.$ sca) was higher than the general combining ability $\left(\sigma^{2} \mathrm{gca}\right)$ in all seasons, indicating the preponderance of nonadditive gene action in inheritance of that trait. Majority of the crosses showing significant sca effects had either one or both the parents were good general combiners. Thus the combining ability of parents may be considered as a reliable guide in the prediction of the yield potential of those crosses. The crosses Nistari Oval (G)×BSRI-98, Nistari×BSRI-98 and BSRI-95× Nan Nung7B are recommended for the commercial exploitation of heterosis as an important egg producing breeds in majority of the rearing seasons.
\end{abstract}

Key words: Heterosis, combining ability, Bombyx mori.

\section{Introduction}

Heterosis has been harnessed in the silkworm by crossing different breeds, inbred lines and geographical races. Only $F_{1}$ hybrids are used for commercial rearing in all sericulturally advanced countries. Several studies have demonstrated significant levels of heterosis in the silkworm, Bombyx mori L. (Ashoka and Govindan 1990, Malik and Krisnamurthy 1994, Rahman and Jahan 1997, Rao, et al. 2003, Boyko et al. 2004). The choice of parents for the exploitation of hybrid vigour and hybridization programme was one of the crucial tasks for the breeders. Sometimes parents with poor performance produce superior offspring while promising parents produce disappointing results (Allard, 1960). The combining ability of the parents would therefore depend on complex per se performance and adaptation of the parents. Methods of evaluating combining ability of parents and other crosses had been devised through linextester design (Kempthorne, 1957) and utilizing diallel progenies (Griffing, 1956a).

In Bangladesh, the concept of introducing $F_{1}$ hybrids for commercial rearing was hardly known before 1990's due to paucity of information on heterosis and lack of knowledge on $F_{1}$ hybrid egg production. However, little attention has been paid on this aspect and no elaborate hybrid vigor study has undertaken by the concerned agencies. Therefore, in the present investigation, heterosis, general and specific combining abilities has been observed in a number of crosses among the varieties with genetic diversity, different geographical origin and voltinism for an important egg producing traits of $B$. mori in four different rearing seasons.

\section{Materials and methods}

In the present experiments five multivoltine viz. Nistari $\left(P_{1}\right)$, Nistari oval $(G)\left(P_{2}\right)$, BSRI-95 $\left(P_{3}\right)$, NanNung-7B $\left(\mathrm{P}_{4}\right)$, BSRI-98 $\left(\mathrm{P}_{5}\right)$ and one bivoltine viz. BV (High) $P_{6}$ ) varieties of silkworm, B. mori. were utilized as parents and were crossed following diallel crossing including reciprocals.

The parents and 30 hybrids were reared in randomized block design with three replications in four rearing seasons corresponding to commercial rearing seasons as practiced by farmers in Bangladesh. These rearing seasons, average room temperature and relative humidity were as follows:

\begin{tabular}{llccc}
\hline $\begin{array}{c}\text { Rearing } \\
\text { seasons } \\
\text { (Local name) }\end{array}$ & $\begin{array}{c}\text { Rearing } \\
\text { period }\end{array}$ & $\begin{array}{c}\text { Code } \\
\text { name }\end{array}$ & $\begin{array}{c}\text { Average } \\
\text { temperature } \\
\left({ }^{\circ} \mathrm{C}\right)\end{array}$ & $\begin{array}{c}\text { Relative } \\
\text { humidity } \\
(\%)\end{array}$ \\
\hline Agrahyoni & October - & S-1 & $23.01 \pm 1.02$ & $91.36 \pm 1.56$ \\
Chaita & $\begin{array}{l}\text { November } \\
\text { March- April }\end{array}$ & S-2 & $29.76 \pm 1.21$ & $92.02 \pm 2.68$ \\
Jaistha & May -June & S-3 & $30.24 \pm 1.81$ & $94.21 \pm 1.81$ \\
Bhaduri & $\begin{array}{l}\text { August- } \\
\text { Setember }\end{array}$ & S-4 & $31.42 \pm 1.63$ & $96.11 \pm 1.12$ \\
\hline
\end{tabular}

The rearing was conducted in the Sericulture Research Laboratory of the Department of Zoology, Rajshahi University. The total number of eggs laid by an individual female moth was counted. A mean of 20 layings for each replication was used for statistical analysis. The average performance of parents and $F_{1}$ hybrids (average over reciprocal crosses) over replications were used for calculating the magnitude of heterosis. 
The general and specific combining ability effects and variances were estimated following Griffings (1956b) Method I. In the model II the experimental material is to be regarded as the population about which inference are to be made. The objectives are to compare combining abilities of the parents when the parents themselves are used as tester and to identify the yielding combinations.

\section{Results and discussion}

The mean performances of the parents and hybrids $\left(F_{1}\right)$ for different rearing seasons have been shown in Table 1. The estimates of heterosis over mid and better parents for different rearing seasons have been presented in Table 2. The degree and direction of heterosis varied for different hybrid population in different rearing seasons. Similar findings have been reported (Sengupta et al., 1971; Rahman, 1986; Strunnikov, 1986; Subba Rao and Sahai, 1989; Datta et al., 2001).

Heterosis over mid-parent ranged from -18.04 to $21.61 \%$ in S-1, -15.74 to $12.86 \%$ in S-2, -21.29 to $20.12 \%$ in S-3 and -21.61 to $27.61 \%$ in S-4 rearing seasons. Of the fifteen crosses, nine crosses in S1 (positive: 6; negative: 3); ten crosses in S-2 (positive: 6; negative: 4) and S-3 (positive: 6; negative: 4) and eight crosses in S-4 (positive: 5; negative: 3 ) showed significant heterosis over their recessive mid parents.

Table.1 Mean performance of parents and hybrids $\left(F_{1}\right)$ in Agrahyoni (S-1), Chaita (S-2), Jaistha (S-3) and Bhaduri (S-4) rearing seasons for total number of eggs laid per female in B. mori L.

\begin{tabular}{ccccc}
\hline Parents & $\mathrm{S}-1$ & $\mathrm{~S}-2$ & $\mathrm{~S}-3$ & $\mathrm{~S}-4$ \\
\hline $\mathrm{P}_{1}$ & 375.407 & 364.673 & 364.050 & 345.573 \\
$\mathrm{P}_{2}$ & 381.627 & 384.427 & 358.320 & 344.750 \\
$\mathrm{P}_{3}$ & 494.607 & 463.620 & 408.183 & 418.797 \\
$\mathrm{P}_{4}$ & 391.860 & 401.797 & 362.487 & 322.287 \\
$\mathrm{P}_{5}$ & 522.847 & 504.413 & 444.783 & 397.637 \\
$\mathrm{P}_{6}$ & 464.920 & 423.760 & 394.310 & 331.617 \\
\hline Crosses & & & & \\
\hline $\mathrm{P}_{1} \times \mathrm{P}_{2}$ & 377.61 & 376.32 & 363.22 & 352.38 \\
$\mathrm{P}_{1} \times \mathrm{P}_{3}$ & 462.41 & 465.21 & 437.35 & 375.88 \\
$\mathrm{P}_{1} \times \mathrm{P}_{4}$ & 378.32 & 335.04 & 328.09 & 298.59 \\
$\mathrm{P}_{1} \times \mathrm{P}_{5}$ & 485.48 & 463.35 & 425.58 & 419.96 \\
$\mathrm{P}_{1} \times \mathrm{P}_{6}$ & 461.65 & 435.47 & 393.54 & 347.37 \\
$\mathrm{P}_{2} \times \mathrm{P}_{3}$ & 364.42 & 357.27 & 353.21 & 299.28 \\
$\mathrm{P}_{2} \times \mathrm{P}_{4}$ & 470.32 & 443.66 & 432.92 & 425.61 \\
$\mathrm{P}_{2} \times \mathrm{P}_{5}$ & 488.82 & 497.91 & 470.99 & 430.74 \\
$\mathrm{P}_{2} \times \mathrm{P}_{6}$ & 428.78 & 434.58 & 391.87 & 386.97 \\
$\mathrm{P}_{3} \times \mathrm{P}_{4}$ & 485.91 & 448.59 & 436.15 & 433.44 \\
$\mathrm{P}_{3} \times \mathrm{P}_{5}$ & 501.85 & 465.98 & 463.02 & 432.58 \\
$\mathrm{P}_{3} \times \mathrm{P}_{6}$ & 466.28 & 445.48 & 424.96 & 386.33 \\
$\mathrm{P}_{4} \times \mathrm{P}_{5}$ & 403.95 & 399.68 & 349.65 & 358.26 \\
$\mathrm{P}_{4} \times \mathrm{P}_{6}$ & 351.11 & 356.53 & 297.84 & 306.95 \\
$\mathrm{P}_{5} \times \mathrm{P}_{6}$ & 550.92 & 505.91 & 462.49 & 313.17 \\
\hline
\end{tabular}

When compared to the better parents the magnitude of heterosis was very low towards the positive direction. The values ranged from -26.32 to $20.02 \%,-22.94$ to $10.42 \%,-24.47$ to $7.14 \%$ and -28.54 to $23.86 \%$ in S-1, S-2, S-3 and S-4 rearing seasons respectively. Only one cross $\left(\mathrm{P}_{2} \times \mathrm{P}_{4}\right)$ in S-1, S-2 and S-3 and two crosses $\left(P_{2} \times P_{4}\right.$, and $P_{2}$ $\left.\times P_{6}\right)$ in $S-4$ exhibited significant positive heterosis over better parents. On the other hand three crosses in S-1; six crosses in S-2 and S-4 and four crosses in S-3 showed significant negative heterosis over better parent (Tables 2).

Table 2. Estimates of heterosis over mid parents and better parents for total egg layings per female in Agrahyoni (S-1), Chaita (S-2), Jaistha (S-3) and Bhaduri (S-4) rearing seasons.

\begin{tabular}{|c|c|c|c|c|c|c|c|c|}
\hline \multirow{2}{*}{ Crosses } & \multicolumn{2}{|c|}{ S-1 } & \multicolumn{2}{|c|}{ S-2 } & \multicolumn{2}{|c|}{ S-3 } & \multicolumn{2}{|c|}{ S-4 } \\
\hline & MP & BP & MP & $\mathrm{BP}$ & MP & $\mathrm{BP}$ & MP & BP \\
\hline$P_{1} \times P_{2}$ & -0.24 & -1.05 & 0.47 & -2.11 & 0.56 & -0.23 & 2.09 & 1.97 \\
\hline$P_{1} \times P_{3}$ & 6.30 & -6.51 & $12.33^{\star *}$ & 0.34 & $13.27^{\star \star}$ & 7.14 & -1.65 & $-10.25^{\star *}$ \\
\hline$P_{1} \times P_{4}$ & -1.39 & -3.46 & $-12.57^{\star *}$ & $-16.61^{\star *}$ & $-9.68^{*}$ & $-9.88^{\star}$ & $-10.58^{\star \star}$ & $-13.60^{* *}$ \\
\hline$P_{1} \times P_{5}$ & $8.09^{*}$ & -7.15 & $6.63^{*}$ & $-8.14^{*}$ & 5.23 & -4.32 & $13.01^{\star *}$ & 5.61 \\
\hline$P_{1} \times P_{6}$ & $9.87^{*}$ & -0.70 & $10.46^{* *}$ & 2.76 & 3.79 & -0.20 & 2.59 & 0.52 \\
\hline$P_{2} \times P_{3}$ & $-16.82^{\star *}$ & $-26.32^{\star \star}$ & $-15.74^{\star *}$ & $-22.94^{\star *}$ & $-7.84^{*}$ & $-13.47^{\star \star}$ & $-21.61^{\star \star}$ & $-28.54^{\star \star}$ \\
\hline $\mathrm{P}_{2} \times \mathrm{P}_{4}$ & $21.61^{\star \star}$ & $20.02^{\star \star}$ & $12.86^{\star \star}$ & $10.42^{\star}$ & $20.12^{\star \star}$ & $19.43^{* *}$ & $27.61^{\star \star}$ & $23.46^{* \star}$ \\
\hline$P_{2} \times P_{5}$ & $8.09^{\star}$ & -6.51 & $12.04^{* *}$ & -1.29 & $17.29^{\star \star}$ & 5.89 & $16.04^{\star *}$ & $8.33^{\star}$ \\
\hline$P_{2} \times P_{6}$ & 1.30 & -7.77 & $7.54^{*}$ & 2.55 & 4.13 & -0.62 & $14.43^{\star \star}$ & $12.25^{\star \star}$ \\
\hline$P_{3} \times P_{4}$ & $9.63^{*}$ & -1.76 & 3.67 & -3.24 & $13.19^{\star \star}$ & 6.85 & $16.97^{\star \star}$ & 3.50 \\
\hline$P_{3} \times P_{5}$ & -1.35 & -4.02 & -3.73 & $-7.62^{*}$ & $8.57^{\star \star}$ & 4.10 & 5.97 & 3.29 \\
\hline$P_{3} \times P_{6}$ & -2.81 & -5.73 & 0.40 & -3.91 & 5.91 & 4.11 & 2.97 & $-7.75^{\star}$ \\
\hline$P_{4} \times P_{5}$ & $-11.68^{* *}$ & $-22.74^{\star *}$ & $-11.79^{\star *}$ & $-20.76^{\star *}$ & $-13.37^{\star *}$ & $-21.39 * *$ & -0.47 & $-9.90^{*}$ \\
\hline$P_{4} \times P_{6}$ & $-18.04^{* *}$ & $-24.48^{\star *}$ & $-13.63^{\star *}$ & $-15.87^{\star \star}$ & $-21.29^{\star *}$ & $-24.47^{\star \star}$ & -6.12 & -7.44 \\
\hline$P_{5} \times P_{6}$ & $11.55^{\star *}$ & 5.37 & 9.01 & 0.30 & $10.23^{\star *}$ & 3.98 & $-14.11^{\star *}$ & $-21.24^{\star \star}$ \\
\hline
\end{tabular}

In general, considerable amount to heterosis was obtained in the crosses where parents Nistari Oval (G), BSRI-98 and BV-High were involved in different seasons. These three breeds showing heterosis in majority of the crosses were picked from diverse genetic origin. These observations are in conformity with the previous findings that greater heterosis is obtained between the crosses of parents of different regions than crosses between closely related parents (Narayanan et al., 1964; Gamo et al., 1985; Tayade, 1987; Govindan et al., 1987; Rahman, 1989; Datta et al., 2001; Farooq et al., 2002). Falconer (1960) also supported this view and reported that the amount of heterosis of a cross depends on the square of the differences of gene frequencies between the populations or lines and therefore, heterosis is not expected where the parental populations do not differ in gene frequencies.

The results of analysis of variance of combining ability have been shown in Table 3 . The mean squares of gca and sca were significant for all the rearing seasons showing a considerable amount of genetic variability in the materials of present 
study. But the reciprocal effects showed nonsignificant results in all the four seasons. The variance of components of general and specific combining abilities and their ratios were showed in Table 4. Estimates of variance due to the general ( $\sigma^{2}$ gca $)$ and specific combining ability $\left(\sigma^{2}\right.$ sca $)$ indicated that the variance due to the specific combining ability was higher in all the seasons showing the predominant role of non-additive type of gene action. A similar picture has also been shown by the ratio $\sigma^{2}$ gca $/ \sigma^{2}$ sca, which were less than unity indicating the predominant of nonadditive gene action in the inheritance of this trait. Non-additive gene actions governing the expression of some quantitative traits have been reported by a number of workers in $B$. mori (Narasimhanna and Shelly, 1979; Subba Rao, 1983; Datta and Pershad, 1989; Ravindra et al., 2000).

Table 3. Analysis of variance of combining ability for total number of eggs laid per female in $B$. mori L in Agrahyoni (S-1), Chaita (S-2), Jaistha (S3 ) and Bhaduri (S-4) rearing seasons.

\begin{tabular}{lrllll}
\hline \multirow{2}{*}{ Source } & d.f. & \multicolumn{4}{c}{ Mean sum of squares for different seasons } \\
\cline { 3 - 6 } & & S-1 & S-2 & S-3 & S-4 \\
\hline gca & 5 & $11255.166^{* *}$ & $8612.329^{*}$ & $7419.129^{* *}$ & $4241.488^{* *}$ \\
sca & 15 & $3695.342^{\star *}$ & $3168.934^{* *}$ & $3066.013^{\star *}$ & $3779.500^{* *}$ \\
Reciprocal & 15 & 130.603 & 56.225 & 48.393 & 38.427 \\
Error & 70 & 175.503 & 132.186 & 120.007 & 118.449 \\
\hline
\end{tabular}

Table 4. Estimates of components of variance due to gca and sca and their ratio for different characters in B. mori L. in Agrahyoni (S-1), Chaita (S-2), Jaistha (S-3) and Bhaduri (S-4) rearing seasons.

\begin{tabular}{lrrrr}
\hline Components & \multicolumn{1}{c}{ S-1 } & \multicolumn{1}{c}{ S-2 } & \multicolumn{1}{c}{ S-3 } & \multicolumn{1}{c}{ S-4 } \\
\hline$\sigma^{2}$ gca & 639.893 & 462.116 & 370.116 & 48.657 \\
$\sigma^{2}$ sca & 2043.760 & 1763.258 & 1710.569 & 2125.753 \\
Reciprocal & -22.450 & -37.980 & -35.807 & -40.011 \\
$\sigma^{2}$ gca / $\sigma^{2}$ sca & 0.313 & 0.262 & 0.217 & 0.023 \\
\hline
\end{tabular}

The general combining ability effect of individual parents with their corresponding standard error have been shown in Table 5. Parent BSRI-98 was found to be the best general combiner in all the rearing seasons. The results revealed that BSRI98 and BSRI-95 were positively significant in all the rearing seasons but BV-High was positively significant only in S-1. On the other hand, majority of the other parents showed negatively significant result. These good general combiners could effectively be utilized in the future hybridization programmes for developing high yielding varieties but it would be difficult to develop pure line with yielding ability equal to $F_{1}$ hybrid, because much of the yielding ability of $F_{1}$ appear to be due to the non-additive type of genetic variance.

Specific combining ability in respect of four different rearing seasons has been presented in Table 6. Estimates of sca effects indicated that out of 15 crosses tested, seven crosses exhibited significant positive sca in S-1 and S-2; five in S-3 and eight in S-4 while four in S-1; six in S-2; five in S-3 and S-4 were negatively significant. Majority of the crosses showing significant positive sca effect were the resultants of at least one good general combining parent except cross $7\left(\mathbf{P}_{\mathbf{2}} \times \mathbf{P}_{\mathbf{4}}\right)$ in all the seasons. Thus the combining ability of parents may be considered as a reliable guide in the prediction of the yield potential of these crosses. The significant positive sca effect shown by cross 7 might have arisen due to genetic interactions. A good number of crosses also showed negatively significant sca effect which might be due to the presence of epistasis.

Table 5. Estimates of general combining ability effects of the parents for total number of eggs laid per female in B. mori L. in Agrahyoni (S-1), Chaita (S-2), Jaistha (S-3) and Bhaduri (S-4) rearing seasons.

\begin{tabular}{|c|c|c|c|c|}
\hline \multirow{2}{*}{ Parents } & \multicolumn{4}{|c|}{ Seasons } \\
\hline & S-1 & S-2 & S-3 & S-4 \\
\hline Nistari & $-17.6456^{* *}$ & $-17.0492^{* *}$ & $-15.2150^{* *}$ & $-9.1811^{* *}$ \\
\hline $\begin{array}{l}\text { Nistari Oval } \\
\text { (G) }\end{array}$ & $-23.9762^{* *}$ & $-13.7428^{\star *}$ & $-6.9675^{*}$ & 2.4908 \\
\hline BSRI-95 & $16.4216^{\star *}$ & $13.2419^{\star *}$ & $21.3628^{\star *}$ & $22.0450^{* *}$ \\
\hline Nan Nung 7B & $-31.8931^{* *}$ & $-31.4958^{\star *}$ & $-30.8331^{* *}$ & $-13.6892^{* *}$ \\
\hline BSRI-98 & $49.6032^{\star *}$ & $43.7433^{\star *}$ & $37.0781^{* *}$ & $21.5506^{\star *}$ \\
\hline BV-High & $7.4902^{*}$ & 5.3025 & -5.4253 & $-23.2161^{* *}$ \\
\hline SE $(\hat{g} i)$ & 3.490 & 3.029 & 2.886 & 2.867 \\
\hline
\end{tabular}

${ }^{*} \mathrm{P}<0.05,{ }^{* *} \mathrm{P}<0.01$

High sca effects of those crosses might be the result of the complementary type of genetic interactions. Cross $11\left(\mathbf{P}_{\mathbf{3}} \times \mathbf{P}_{\mathbf{5}}\right)$ in S-3 exhibited significant heterosis as well as they were the product of good general combining parents. But they did not show significant specific combing ability (Tables 2 and 6). High sca denotes, a high heterotic response but this may be due to the very poor performance of the parents in comparison to their hybrids. With the same amount of heterotic effect the sca effect may be less where the mean performances of the parents were higher (Ahmed et al., 1979). This suggests that the selection of cross combinations based on the heterotic response would be more realistic. 
Table 6. Estimates of specific combining ability and reciprocal effects for total number of eggs laid per female in B. mori $\mathrm{L}$ in Agrahyoni (S-1), Chaita (S-2), Jaistha (S-3) and Bhaduri (S-4) rearing seasons.

\begin{tabular}{|c|c|c|c|c|c|c|}
\hline & \multirow{2}{*}{$\begin{array}{c}\text { Cross } \\
\text { No. }\end{array}$} & \multirow{2}{*}{ Crosses } & \multicolumn{4}{|c|}{ Seasons } \\
\hline & & & S-1 & $\mathrm{S}-2$ & S-3 & S-4 \\
\hline \multirow{15}{*}{ 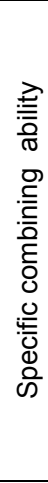 } & 1 & $\mathrm{P}_{1} \times \mathrm{P}_{2}$ & $-21.4435^{\star \star}$ & $-14.5672^{\star}$ & $-17.4211^{*}$ & -9.9394 \\
\hline & 2 & $\mathrm{P}_{1} \times \mathrm{P}_{3}$ & $27.9004^{* \star}$ & $43.8997^{* *}$ & $36.4969^{* \star}$ & 2.2081 \\
\hline & 3 & $P_{1} \times P_{4}$ & -12.6249 & $-40.1408^{\star *}$ & $-26.4389^{\star *}$ & $-42.3211^{\star \star}$ \\
\hline & 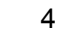 & $\mathrm{P}_{1} \times \mathrm{P}_{5}$ & $17.9487^{\star}$ & $18.6467^{* *}$ & 2.0517 & $42.7608^{\star \star}$ \\
\hline & 5 & $P_{1} \times P_{6}$ & $22.0801^{\text {** }}$ & $22.6392^{* *}$ & 12.8333 & $14.0292^{*}$ \\
\hline & 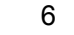 & $P_{2} \times P_{3}$ & $-73.5124^{\star \star}$ & $-71.3083^{\star *}$ & $-60.6156^{\star *}$ & $-95.8089^{\star \star}$ \\
\hline & 7 & $P_{2} \times P_{4}$ & $88.9223^{\star *}$ & $57.8478^{* *}$ & $67.0519^{* *}$ & $62.2569^{* *}$ \\
\hline & 8 & $P_{2} \times P_{5}$ & $21.6609^{\star \star}$ & $38.0586^{* *}$ & $42.4108^{\star *}$ & $35.2006^{* \star}$ \\
\hline & 9 & $P_{2} \times P_{6}$ & -0.6477 & 7.3061 & -1.6792 & $39.1956^{\star *}$ \\
\hline & 10 & $P_{3} \times P_{4}$ & $34.2345^{\star \star}$ & $41.4547^{\star *}$ & $43.4950^{\star \star}$ & $50.1494^{\star \star}$ \\
\hline & 11 & $P_{3} \times P_{5}$ & -9.8119 & $-25.8694^{\star *}$ & 8.0972 & $16.5047^{\star}$ \\
\hline & 12 & $P_{3} \times P_{6}$ & 3.9845 & 3.9364 & 9.0706 & $22.9131^{\star \star}$ \\
\hline & 13 & $\mathrm{P}_{4} \times \mathrm{P}_{5}$ & $-49.8505^{\star \star}$ & $-47.7133^{* *}$ & $-52.0303^{\star *}$ & $-21.9461^{\star x}$ \\
\hline & 14 & $\mathrm{P}_{4} \times \mathrm{P}_{6}$ & $-71.7691^{\star \star}$ & $-46.9875^{\star *}$ & $-54.2286^{* *}$ & $-27.1311^{\star *}$ \\
\hline & 15 & $\mathrm{P}_{5} \times \mathrm{P}_{6}$ & $40.9712^{\star \star}$ & $29.2000^{* *}$ & $30.8453^{* *}$ & $-56.3825^{\star \star}$ \\
\hline \multirow{17}{*}{ 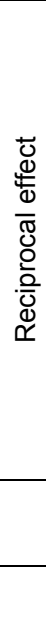 } & 1 & $\mathrm{P}_{1} \times \mathrm{P}_{2}$ & -3.8867 & -7.5733 & 0.8 & -1.6600 \\
\hline & 2 & $P_{1} \times P_{3}$ & -8.8250 & -4.1350 & -7.3 & -9.8650 \\
\hline & 3 & $P_{1} \times P_{4}$ & -4.0783 & -5.5200 & -1.4 & -6.8950 \\
\hline & 4 & $P_{1} \times P_{5}$ & -8.9817 & -11.2433 & -0.3 & -5.8433 \\
\hline & 5 & $P_{1} \times P_{6}$ & 5.1633 & -4.6750 & -0.6 & -4.9 \\
\hline & 6 & $\mathrm{P}_{2} \times \mathrm{P}_{3}$ & 0.9250 & -0.1667 & -2.5 & -0.1200 \\
\hline & 7 & $\mathrm{P}_{2} \times \mathrm{P}_{4}$ & -7.2950 & 1.8050 & 1.6667 & 3.8817 \\
\hline & 8 & $P_{2} \times P_{5}$ & -3.0267 & 0.5983 & -3.5333 & 0.8283 \\
\hline & 9 & $P_{2} \times P_{6}$ & 1.3517 & 6.4617 & 3.9433 & -2.1767 \\
\hline & 10 & $P_{3} \times P_{4}$ & $22.5883^{\star}$ & -3.8633 & 0.1200 & 4.2583 \\
\hline & 11 & $P_{3} \times P_{5}$ & 1.0783 & 5.6150 & -5.520 & 1.8100 \\
\hline & 12 & $P_{3} \times P_{6}$ & -6.1750 & -6.2533 & -2.0533 & -6.0817 \\
\hline & 13 & $\mathrm{P}_{4} \times \mathrm{P}_{5}$ & -8.4683 & 5.9000 & -6.5667 & 1.6717 \\
\hline & 14 & $\mathrm{P}_{4} \times \mathrm{P}_{6}$ & 2.7267 & 0.4583 & -13.6783 & 0.31 \\
\hline & 15 & $\mathrm{P}_{5} \times \mathrm{P}_{6}$ & 8.2967 & -1.5883 & -2.0133 & 0.5450 \\
\hline & \multicolumn{2}{|c|}{$\mathrm{SE}(\hat{\mathrm{Sij}})$} & 7.961 & 6.909 & 6.583 & 6.540 \\
\hline & \multicolumn{2}{|c|}{$\mathrm{SE}(\hat{\mathrm{r}} \mathrm{ij})$} & 9. & .130 & 7.746 & 7.696 \\
\hline
\end{tabular}

${ }^{*} \mathrm{P}<0.05,{ }^{* *} \mathrm{P}<0.01$

During the evaluation of the merit of the crosses due consideration should be given on all the three parameters of study, viz. magnitude of heterosis, estimates of gca and sca. It is evident from the results that cross 8, "Nistari Oval (G)×BSRI-98", cross 4, "Nistari×BSRI-98" and cross 10, "BSRI95× Nan Nung7B" exhibited the best performance as an important egg producing breeds in majority of the rearing seasons.

It is interesting to note that performance of a cross in a season did not necessarily give good performance in other seasons, i.e., the expressions of these quantitative traits were season specific. Here cross 5, "Nistarix BV-High" in S-1, S-2 and cross 15, "BSRI-98×BV-High" in S1 , S-3 exhibited a promising performance. Therefore, it is suggested that $F_{1}$ hybrids should to be identified for their commercial exploitation specific to deferent rearing seasons. Heterosis over better parents are very limited in this study which is always desirable for maximum gains and for this, there is need for searching genetically diverse materials.

\section{Reference}

Ahmed, Z., Kumar, R., Katiyar, P. \& Gupta, R.R. 1979. Heterosis in macaroni wheat. Indian J. Genet. Plant Breed. 39: 279-284.

Allard, R.W. 1960.The analysis of genetic environment interactions by means of diallel crosss. Geneticcs 41: 305-315.

Ashoka, J. \& Govindan, R. 1990. Heterosis for pupal and related traits in single and double cross hybrids of bivoltine silkworm, Bombyx mori L. Entomon 15(2\&3): 302-306.

Boyko Y. A., Sukhanov, S. V. \& Shakhbazov V. G.. 2004. The effect of heterosis and inheritance of quantitative traits in silkworm exposed to electromagnetic irradiation. Russian J. Genet. 40(9): 990-994.

Datta, R.K. \& Pershad, G.D. 1989. Combining ability among multivoltine and bivoltine silkworms Bombyx mori L., hybrids. Sericologia 28(1): 21-29.

Datta, R.K., Raghavendra, R.D., Jayaswal, K.P., Premalatha, V., Singh, R. \& Kariappa, B.K. 2001. Heterosis in relation to combinig ability in multi $x$ bivoltine strains of silkworm, Bombyx mori L. Indian J. Seric. 40(1): 1- 6 .

Falconer, D.S. 1960. Introduction to Quantitative Genetics. Edinburgh and London. Oliver and Boyd. 286pp

Farooq, M., Puttaraju, H.P., Dar, H.V. \& Sofi, A.M. 2002. Heterosis in relation to genetic divergence in bivoltine silkworm, Bombyx mori. Indian $\mathrm{J}$. Seric. 41(1): 10-18.

Gamo, T., Otsuka, Y., Fujishima, T., Hirobe, T. \& Tazima, Y. 1985. Estimation of combining ability and genetic analysis by diallel crosses between regional races of silkworm (1) Rearing performances and cocoon yields. Tech. Bull. Seri. Expt. Sta. 126: 93-120.

Govindan, R., Magadum, S.B. \& Satenahalli, S.B. 1987. Breeding with some polyvoltine and bivoltine stains of the silkworm, Bombyx mori L. Sericologia 27: 597-604.

Griffing, B. 1956a. A generalized treatment of diallel crosses in quantitative inheritance. Heredity 10: 31-50.

Griffing, B. 1956b. Concept of general and specific combining ability in relation to diallel crossing system. Aus. J. Biological Sci. 9: 463-493.

Kempthorne, O. 1957. An Introduction to Genetic statistics. Jonh Willey and Sons, New York. pp 545. 
Malik M. A. \& Krisnamurthy N. B. 1994. Studies on the evaluation of heterosis in a few bivoltine hybrids of Bombyx mori L. under temperate conditions. Bull. Sericult. Res. 5, 25-30.

Narasimhanna, M.N. \& Shelly, M.R. 1979. Line $\times$ tester analysis of Bombyx mori L. Isolation of multivoltine hybrids for Karnataka state.E.S. AP. Bangalore.

Narayanan, E.S., Rao, L.S. \& Venkataramu, C.V. 1964. A contribution to our knowledge of crossing interregional seed cocoons to arrest depression in the Mysore silkworm races. Indian J. Seric. 3: 11-15.

Rahman, S.M. 1986. Heterosis for egg production and hatching percentage in silkworm, Bombyx mori L. (Lepidoptera: Bombycidae). J. Asiatic Soc. Bangladesh. 12: 21-25.

Rahman, S.M. 1989. Studies on genetic and genotypeenvironment interactions of some quantitative characters in silkworm, Bombyx mori $\mathrm{L}$. (Lepidoptera: Bombycidae). Ph. D. Thesis, Rajshahi University, Rajshahi.

Rahman S. M. \& Jahan M. S. 1997. Heterosis and combining ability estimates for cocoon breadth in silkworm, Bombyx mori L. Bull Sericult. Res 8: 7-11.

Rao PS, Datta RK, Basavaraja HK, Rekha M. \& Vijayakumari KM. 2003. Analysis of heterosis and combining ability of certain quantitative traits in silkworm Bombyx mori L. under different temperature and humidity conditions. Indian $\mathrm{J}$. Seric 42(2), 152-157.

Ravindra, S., Kalpana, G.V., Rao, P.S., Ahsan, M.M., Datta, R.K \& Rekha, M. 2000. Studies on combining ability and heterosis in the silkworm, Bombyx mori L. Indian J. Seric. 39(1): 43-48

Sengupta, K., Datta, R.K., Biswas, S.N \& Singh, B.D. 1971. Studies on the heterosis in multivoltine silkworm, Bombyx mori L. I. Yield performance of $F_{1}$ hybrids of Nistari and four evolved multivoltine breeds. Indian J. Seric. 10: 6-13.

Strunnikov, V.A. 1986. Nature of heterosis and combining ability in the silkworm. Theor. Appl. Genet. 72: 503-512.

Subba Rao, G. 1983. Line $\times$ tester analysis of some characters in bivoltine silkworm. National Seminar on Silk Research and Development. March 10-13, Bangalore, India pp 16.

Subba Rao, G. \& Sahai, V. 1989. Combining ability and heterosis in bivoltine strains of silkworm, Bombyx mori L. Uttar Pradesh J. Zool. 9(2): 150-164.

Tayade, D.S. 1987. Heterosis effect of economic traits of new hybrids of silkworm, Bombyx mori L. Marathwada conditions. Sericologia 27(2): 301-307. 